\title{
Analysis and Study on the determination results of compaction degree of foundation treatment
}

\author{
ZHU Xunguo ${ }^{1, a}$ \\ 1.College of Architectural Engineering , Dalian University, Dalian , Liaoning 116622 , China \\ 2. Liaoning Provincial Key Laboratory for disaster predicting and controlling of Complex structural \\ system Dalian University , Dalian Liaoning 11662 , China \\ zhu_xunguo@hotmail.com
}

Keywords: Foundation treatment; theoretical analysis; compaction degree; sand filling method. Abstract. Determination of compaction degree is an important method in the foundation treatment, especially in the foundation quality detection after the replacement of crushed stone. According to the basic engineering, foundation treatment and other relevant theoretical knowledge, to calculate the degree of compaction of the first compacted soil compaction test of soil samples, the optimum water content and maximum dry density determination of soil dry density, then through in-situ sand filling method for determination of soil samples, according to the calculation formula of the degree of compaction of soil. In this paper, the theory is applied to analyze the actual engineering, and the corresponding calculation results are obtained. The experimental method of this paper has certain guiding significance for similar projects.

\section{Introduction}

The soil test is a course of civil engineering students must master, because it involves a large number of theoretical and practical skills, master will directly affect the subsequent professional courses and related issues involved in the future work so as to teachers and students are very important.

However, there are many problems in the teaching of civil engineering experiment. For example, textbook theory and national standards are not unified, lack of teaching equipment and equipment, as well as the actual operation of the students the opportunity to operate very little and so on [1]. The above reasons lead to the teachers in the teaching of obscure, students learning difficult, and even do not know their situation. The author in recent years of teaching practice, the biggest problem is the teaching and practical operation of the line.

At present, most of the colleges and universities are generally divided into two types of geotechnical tests, one is to conduct an independent test of geotechnical tests, and one is relying on relevant courses for the test [2]. In our school, for example, due to the constraints of teachers and testing equipment, the current civil engineering professional all the experimental classes are carried out in second ways. Soil mechanics and engineering geology. The soil test of soil mechanics can only perform simple indoor shear test and triaxial test of three false, a slightly more complex test point, such as the three axle test, soil seepage test and vane test cannot be carried out, therefore, in teaching only by pictures or echo what the books say in the form of. As a result, the students in the study cannot realize the true feeling, and even more confused to explain the situation.

\section{The idea and purpose of the experiment}

In order to solve the above problems, the author after thinking and exploration in long time, and with the Department of a number of teachers exchange, explore a feasible teaching ideas, and some attempts in teaching practice. After a period of practice and reform, gradually formed the following ideas: in the reform of the system of learning the theory of knowledge under the premise of specific projects, put forward the experimental task first, then according to the content of design experiment process, using the theoretical knowledge learned complete experimental tasks. Its purpose is to 
improve the current teaching theory of light practice, emphasizing the disadvantages of light operation. To cultivate students' learning interest and practical ability, and promote the improvement of teaching quality.

In order to cultivate students' ability and rigorous thinking, strict requirements of the students in accordance with national norms and national standards for the test operation and test report writing. There are two purposes, one is teaching in the theory and the current practice of some consistent national standards or norms, some backward and national standards and norms, therefore, strict implementation of national norms and standards can not only cultivate students' test process correctly, but also can further deepen students' awareness of the law of national standards or regulations. The second is to cultivate students' rigorous spirit. The formulation of national standards and norms is a lot of summary and practice, therefore, every step of the operation and calculation are very strict and correct. Therefore, in the study in strict accordance with national standards and norms for the operation can greatly improve the student's rigorous spirit.

\section{Engineering case analysis}

Below with specific cases to illustrate. In the highway construction project, the compaction degree is one of the important indexes to control the quality of the project. In "highway engineering quality inspection and evaluation standard", the weight of subgrade and pavement compaction degree is 3 , and the importance of the degree of compaction in engineering quality control is obviously. In the same way, it is also very important to measure the degree of compaction in the foundation treatment, especially in the foundation quality detection after the replacement of crushed stone. According to the basic engineering, foundation treatment, subgrade and pavement engineering and other related knowledge, for the calculation of the degree of compaction of the first compacted soil compaction test of soil samples, the optimum water content and maximum dry density determination of soil dry density, then through in-situ sand filling method for determination of soil samples, according to the calculation formula of soil the degree of compaction.

\section{Theoretical knowledge collection}

According to the calculation of the degree of compaction process, according to the author put forward the teaching reform ideas to operate. First of all, the degree of compaction measurement involves the relevant theoretical knowledge and national standards and national norms for the collection and careful study, in order to be able to be more familiar with most of the content as the standard. Because it involves the indoor compaction test and the relevant content of the sand filling test, therefore, the current national standards in the relevant standards are listed. Soil compaction test standard (SL237-011-1999), [3] (GB/T50123-1999) [4]. Standard Practice for the regulation of soil testing procedures (T0111-93) part III .

\section{Specific engineering cases}

The foundation engineering of the office building of Dalian Port Railway Company is located in the hospital of Dalian Port railway company, and the foundation treatment adopts the replacement method. The design requirements of the backfill soil compaction is not less than $94 \%$, the foundation bearing capacity is not less than $150 \mathrm{KPa}$. For the foundation can meet the design requirements of inspection after foundation treatment, by the Dalian Port railway company commissioned, Dalian Modern Engineering Testing Co. Geotechnical Engineering Laboratory for compaction and static load test on the foundation of Dalian Port railway company office building.

According to the requirements of Party A and the reference site and the actual situation of the project, on the basis of backfill soil compaction test, each layer 4, a total of 4, a total of 163 point compaction test, static load test of construction site layout.

The detection work strictly on the basis of "technical code for ground treatment of buildings" (JGJ79-2012) [5], "design code of building foundation" (GB50007-2011) [6], "code for investigation of geotechnical engineering" (GB50021-2009) on the current specification [7]. According to the test results, the foundation compaction degree and bearing capacity of the foundation are evaluated. 


\section{Experimental design process}

In this paper, only the degree of compaction as an example, therefore, the compaction test procedures are as follows: soil compaction test, the field test of sand filling method, compaction degree calculation, test report writing.

After the test process is determined, the next step is to determine the test equipment and specific test procedures, as well as the process of calculation and calibration of test data, according to the national standards and national standards for each test. As the main equipment of compaction test is heavy compaction instrument, scales, scales, standard sieve, sample injector, sprinkler etc.. The test procedure for the preparation of specific test samples, the test is completely in accordance with the national standard of compaction test. According to the test results, the water content and dry density of soil sample are calculated, and the curve diagram is drawn.

According to this project, the relationship between the water content and the dry density of the sample is shown in Figure 1:

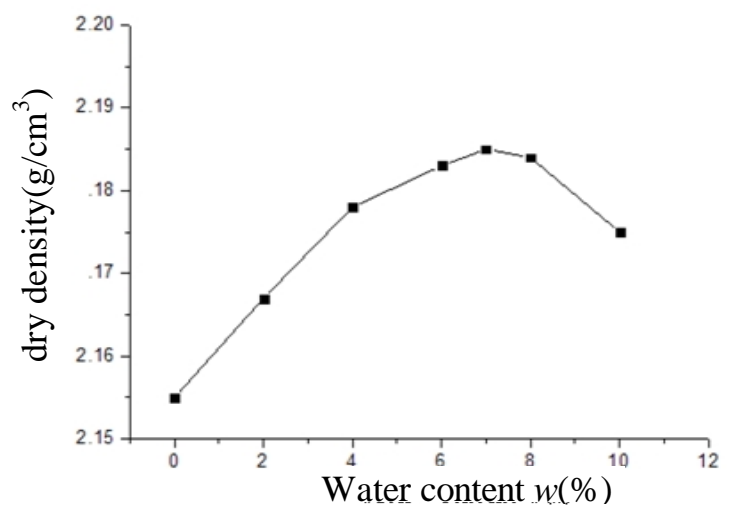

Figure.1 The relation graph between dry density and water content

The maximum dry density and optimum moisture content of the vertical and horizontal coordinates of the peak point on the curve representing the soil, gravel soil can be ascertained by the maximum dry density is $2.185 \mathrm{~g} / \mathrm{cm}^{3}, 7.18 \%$ the optimum water content.

After determining the maximum dry density and the optimum water content of compacted soil samples, according to the test procedure, the following parameters should be determined, such as dry density, moisture content and so on. The test to determine these parameters we design is used in field sand filling method for sand filling method with the main equipment balance, sand barrels, metal cans, calibration substrate, chisel, hammer, aluminum box, long spoon, brush, ovens and other equipment. Concrete test steps in strict accordance with the "geotechnical test procedures" or "highway geotechnical test procedures" in the sand filling method of test steps. The test results are calculated, corrected and recorded.

According to the test section of the specification, after the determination of the water content, dry density and other related parameters of each layer after compaction, the calculation of the relevant parameters such as the following table 1 4. According to the calculation formula of the degree of compaction $K=\rho / \rho_{0}$, which $\rho$ is the dry density of the gravel soil in the field, the compaction degree of each layer of backfill is calculated as shown in table 1 4.

Table 1 The first layer backfill compaction degree test data sheet

\begin{tabular}{|c|c|c|c|c|c|c|}
\hline $\begin{array}{c}\text { Measuring point } \\
\text { Serial number }\end{array}$ & $\begin{array}{c}\text { Test hole } \\
\text { volume }\left(\mathrm{cm}^{3}\right)\end{array}$ & $\begin{array}{c}\text { Test hole soil } \\
\text { weight }(\mathrm{g})\end{array}$ & $\begin{array}{c}\text { Moisture } \\
\text { content }\end{array}$ & $\begin{array}{c}\text { Wet density } \\
\left(\mathrm{g} / \mathrm{cm}^{3}\right)\end{array}$ & $\begin{array}{c}\text { Dry density } \\
\left(\mathrm{g} / \mathrm{cm}^{3}\right)\end{array}$ & $\begin{array}{c}\text { compaction degree } \\
\left(K=\rho / \rho_{0} \%\right)\end{array}$ \\
\hline 1 & 1837 & 4033 & $3.5 \%$ & 2.20 & 2.12 & 97 \\
\hline 2 & 1897 & 4271 & $5.4 \%$ & 2.25 & 2.14 & 98 \\
\hline 3 & 2231 & 4985 & $5.2 \%$ & 2.23 & 2.12 & 97 \\
\hline 4 & 1973 & 4321 & $6.0 \%$ & 2.19 & 2.07 & 95 \\
\hline
\end{tabular}


Table 2 The second layer backfill compaction degree test data sheet

\begin{tabular}{|c|c|c|c|c|c|}
\hline $\begin{array}{c}\text { Test hole } \\
\text { volume }\left(\mathrm{cm}^{3}\right)\end{array}$ & $\begin{array}{c}\text { Test hole soil } \\
\text { weight }(\mathrm{g})\end{array}$ & $\begin{array}{c}\text { Moisture } \\
\text { content }\end{array}$ & $\begin{array}{c}\text { Wet density } \\
\left(\mathrm{g} / \mathrm{cm}^{3}\right)\end{array}$ & $\begin{array}{c}\text { Dry density } \\
\left(\mathrm{g} / \mathrm{cm}^{3}\right)\end{array}$ & $\begin{array}{c}\text { compaction degree } \\
\left(K=\rho / \rho_{0} \%\right)\end{array}$ \\
\hline 2196 & 4830 & $5.3 \%$ & 2.20 & 2.09 & 96 \\
\hline 2391 & 5290 & $6.4 \%$ & 2.21 & 2.08 & 95 \\
\hline 2289 & 5019 & $5.1 \%$ & 2.19 & 2.09 & 96 \\
\hline 1883 & 4250 & $5.7 \%$ & 2.26 & 2.14 & 98 \\
\hline
\end{tabular}

Table 3 The third layer backfill compaction degree test data sheet

\begin{tabular}{|c|c|c|c|c|c|c|}
\hline $\begin{array}{c}\text { Measuring point } \\
\text { Serial number }\end{array}$ & $\begin{array}{c}\text { Test hole } \\
\text { volume }\left(\mathrm{cm}^{3}\right)\end{array}$ & $\begin{array}{c}\text { Test hole soil } \\
\text { weight }(\mathrm{g})\end{array}$ & $\begin{array}{c}\text { Moisture } \\
\text { content }\end{array}$ & $\begin{array}{c}\text { Wet density } \\
\left(\mathrm{g} / \mathrm{cm}^{3}\right)\end{array}$ & $\begin{array}{c}\text { Dry density } \\
\left(\mathrm{g} / \mathrm{cm}^{3}\right)\end{array}$ & $\begin{array}{c}\text { compaction degree } \\
\left(K=\rho / \rho_{0} \%\right)\end{array}$ \\
\hline 1 & 2735 & 6076 & $4.0 \%$ & 2.22 & 2.14 & 98 \\
\hline 2 & 2459 & 5386 & $4.5 \%$ & 2.19 & 2.10 & 96 \\
\hline 3 & 2336 & 5164 & $4.4 \%$ & 2.21 & 2.12 & 97 \\
\hline 4 & 2348 & 5217 & $3.8 \%$ & 2.22 & 2.14 & 98 \\
\hline
\end{tabular}

Table 4 The forth layer backfill compaction degree test data sheet

\begin{tabular}{|c|c|c|c|c|c|c|}
\hline $\begin{array}{c}\text { Measuring point } \\
\text { Serial number }\end{array}$ & $\begin{array}{c}\text { Test hole } \\
\text { volume }\left(\mathrm{cm}^{3}\right)\end{array}$ & $\begin{array}{c}\text { Test hole soil } \\
\text { weight }(\mathrm{g})\end{array}$ & $\begin{array}{c}\text { Moisture } \\
\text { content }\end{array}$ & $\begin{array}{c}\text { Wet density } \\
\left(\mathrm{g} / \mathrm{cm}^{3}\right)\end{array}$ & $\begin{array}{c}\text { Dry density } \\
\left(\mathrm{g} / \mathrm{cm}^{3}\right)\end{array}$ & $\begin{array}{c}\text { compaction degree } \\
\left(K=\rho / \rho_{0} \%\right)\end{array}$ \\
\hline 1 & 2363 & 5181 & $3.6 \%$ & 2.19 & 2.12 & 97 \\
\hline 2 & 2926 & 6337 & $3.0 \%$ & 2.17 & 2.10 & 96 \\
\hline 3 & 2514 & 5543 & $4.0 \%$ & 2.21 & 2.12 & 97 \\
\hline 4 & 2598 & 5644 & $4.1 \%$ & 2.17 & 2.09 & 95 \\
\hline
\end{tabular}

According to the compaction degree test of the foundation of the Dalian Port railway company, the compaction degree of the first to four layer is greater than $94 \%$, which meets the requirements of design and specification. This conclusion is based on the conclusion of the design process.

\section{Conclusions}

Based on the analysis of the existing problems of "soil test" teaching, points out the existing problems in the teaching, and according to some of their own ideas and practice in the teaching reform and exploration are made a point of "soil test" teaching, formed on the basis of the theory, using the specific test operation as the carrier the teaching mode. And through the specific case to explain.

In the actual teaching, according to the above ideas to reform and explore the curriculum, and actively improve the relevant aspects of the problem. Practice has proved that students' interest is greatly improved, especially the ability to get a good exercise. At the same time, actively participate in the specific projects of teachers and research groups. It will combine theory and practice, to make up for lack of knowledge in the classroom, even pointed out that different specifications and materials in the present, these are valuable. Therefore, it can be said that these are very useful for the exploration of the teaching reform of the "soil test", but also for the future to further improve and architecture innovation has laid a certain foundation and confidence.

\section{Acknowledgements}

This work was financially supported by the Natural Science Foundation (51374045), Thanks for the test data provided by associate professor Zhao of Dalian University of Technology, Institute of rock and soil engineering, and put forward a lot of valuable suggestions in the writing of the article. 


\section{References}

[1] FU Chao, CHEN Jin-run, CHEN Shi-Feng. Study on teaching reform of the course about Soil Mechanics and Foundation Engineering [J]. 2011, 37(25):240-241

[2] HE Cheng-yi, SHENG Ke-jian, WANG Li -rong, DING Jian-ting. Reformation and Discussion on Practical Teaching Methods for the Course of Foundation Engineering [J]. 2010, 60(4):126-128

[3] Nanjing hydraulic research institute. Specification of soil test (SL137-1999) [S]. Beijing: china water power press, 1999.

[4] The ministry of water resources of the people's republic of china. Standard for soil test method (GB/T50123-1999) [S]. Beijing: the china planning press, 1999

[5] China academy of architectural engineering. Technical code for ground treatment of buildings (GJ79-2012) [S]. Beijing: China building industry press, 2012.

[6] China academy of architectural engineering. Code for design of building foundation (GB50007-2011) [S]. Beijing: China building industry press, 2011.

[7] China academy of architectural engineering. The rock soil engineering reconnaissance specification (GB50021-2009) [S]. Beijing: China building industry press, 2009. 